\title{
Alternatives to Bench Terraces on the Hillsides of Jamaica: II. Cropping Systems and Yields ${ }^{1}$
}

\author{
Abdul H. Wahab, Bo-Myeong Woo, Franklin Rosales, Joseph Dehaney, \\ and Miguel A. Lugo-López ${ }^{2}$
}

\begin{abstract}
Various cropping systems for yam production were tested in the runoff plots at the Olive River Watershed where soil losses were measured. Yellow yam yields ranged between 42 and $63 \mathrm{t} / \mathrm{ha}$, but differences were not significant for either of the two experimental years. Marketable yields were $47 \%$ to $57 \%$ of the gross yields. When yam was intercropped with Irish potato, gross yields of potato ranged from 12 to $14 \mathrm{t} / \mathrm{ha}$. Marketable yields were 80 to $85 \%$ of the gross yields. The lower yam yields in treatments with more than one intercrop were offset by the extra cash flow produced by the intercrops. When the 2year data were pooled, significant yield differences between treatments were obtained, indicating that intercrops affect yam yields adversely. The Napier grass buffer strip produced 42 to $48 \mathrm{t} / \mathrm{ha} / \mathrm{yr}$ (green weight). Alternative soil conservation measures, other than bench terracing, such as hillside ditches and grass buffer strips, and intercropping with yam, increased production and crop diversification in hillsides; are relatively cheaper, simpler, easier to construct, and very effective in terms of soil conservation in the hillsides.
\end{abstract}

\section{INTRODUCTION}

The effectiveness of alternative approaches to bench terracing for reducing soil losses in yam plantings on the hillsides of Jamaica at the Olive River Watershed, with a $20 \%$ slope, has been previously reported. ${ }^{3}$ Losses were reduced by $35 \%$ with hillside ditches and intercropping the yam with Irish potatoes. Reductions of $65 \%$ were further measured from plots of yam intercropped with Irish potato on continuous contour mounds with a grass buffer strip. This paper reports on yields obtained in the runoff plots during the same period.

\section{MATERIALS AND METHODS}

\section{CROPPING SYSTEMS AND MANAGEMENT}

Yellow yam (Dioscorea cayenensis) "heads" were planted March 25, 1980, for the first year experiment, and February 20, 1981, for the second

${ }^{1}$ Manuscript submitted to Editorial Board June 15, 1984.

${ }^{2}$ Former Agricultural Research Specialist IICA/Jamaica, now Assistant Agricultural Development Officer U.S. AID/Haiti; Soil Conservation Specialist, IICA/Jamaica; Agricultural Research Specialist IICA/Jamaica; Soil Conservation Officer, Ministry of Agriculture, Jamaica; and Professor and Soil Scientist (ret.), now Consultant, College of Agricultural Sciences, University of Puerto Rico, Mayagüez Campus.

${ }^{3}$ Wahab, A. H., M. A. Lugo-López, W. Bo-Myeong, F. Rosales and J. Dehaney, 1983. Alternatives to bench terraces on the hillsides of Jamaica: I. Soil Losses, J. Agric. Univ. P.R. 69 (3): 255-64.

${ }^{4}$ Propagation material. 
year experiment on the same plots. The experiments followed a complete block layout with two replications. The size of the experiment had to be limited because of the high expense of building the runoff plots. Information on erosion control treatments is given elsewhere. ${ }^{3}$

In cases where individual hills were constructed, they were spaced 1.5 $\mathrm{m}$ apart along the contour and $1.4 \mathrm{~m}$ along the slope. The height of the hill from the soil surface was approximately $60 \mathrm{~cm}$. Hillside ditches 2.5 $m$ wide were constructed approximately midway down the runoff plots. Contour mounds extended across the plots and were spaced $1.5 \mathrm{~m}$ apart with a height of $60 \mathrm{~cm}$ at the peak. Napier grass buffer strips, $1.3 \mathrm{~m}$ wide, were established about midway down the plot. Irrespective of soil conservation treatment and cropping pattern, 32 heads were planted in each plot to produce an expected population of 8,000 yam plants/ha.

Twenty individual hills/plot were constructed where the traditional individual hill method was used for growing yam with each of 12 hills receiving two heads and each of the remaining hills receiving one head (Treatment 1). Following the traditional system, each hill was provided with one bamboo stake, 5-6 m long, to accommodate the twining yam vine.

In Treatment 2 there were 16 hills, each with two yam heads. Each hill was provided with one bamboo stake.

In Treatment 3 there were eight continuous mounds with four yams heads/mound. Yam heads were placed at $62 \mathrm{~cm}$ intervals along the mound, with mounds spaced $1.5 \mathrm{~m}$ apart. Bamboo stakes were also placed between each pair of mounds and carried four yam vines, two from each mound.

In Treatment 4 there were nine continuous mounds: in five mounds four heads were planted, whereas in the rest, three heads/mound were planted. Spacings in the mound were $62 \mathrm{~cm}$ in case of the four heads and $80 \mathrm{~cm}$ in case of three heads planted/mound. Bamboo stakes were placed as in Treatment 3.

Irish potato was planted in rows $40 \mathrm{~cm}$ apart at intervals of $30 \mathrm{~cm}$ within the row for a density of 33,250 plants/ha. Following the harvest of the Irish potato, radish was sown in rows $30 \mathrm{~cm}$ apart at $10 \mathrm{~cm}$ intervals within rows for a plant population of approximately 125,000 plants/ha. After harvesting the radish, peanuts were sown in rows $40 \mathrm{~cm}$ apart and at a $20 \mathrm{~cm}$ interval within rows for an expected density of approximately 63,000 plants/ha. However, yam was intercropped only with Irish potato for the second year experiment because of the effect of yam shade in the second intercrop.

The ameliorate soil acidity ( $\mathrm{pH} 4.8$ ) and low organic matter content, all plots were limed with $\mathrm{CaCO}_{3}$ as marl, at the rate of $3 \mathrm{t} / \mathrm{ha}$ and 
decomposed sewage sludge. Following this application, the plots were forked and the appropriate conservation treatments installed.

Table 1 shows that each cropping system received the equivalent of $1,460 \mathrm{~kg} / \mathrm{ha}$ of a 12:24:12 fertilizer plus an application of $60 \mathrm{~kg} / \mathrm{ha}$ of $\mathrm{N}$ as urea or ammonium sulphate. Applications in 1980-81 were split as shown in table 2. Fertilizer application for the second year was split in two. At 10 weeks after planting, each plot received the equivalent of 687 $\mathrm{kg} / \mathrm{ha}$ of 7-14-14. The second application was made 5 weeks later with the same amount of 7-14-14 plus $240 \mathrm{~kg} / \mathrm{ha}$ of ammonium sulfate.

In the case of yams, the fertilizers were placed yearly in bands $15 \mathrm{~cm}$ away from the stem, at a depth of $5-7.5 \mathrm{~cm}$. During the first year, applications to the intercrops, except radish, were made at sowing directly

TABLE 1.-Fertilizer regime for the soil conservation and cropping system trials (1980-1981)

\begin{tabular}{|c|c|c|c|}
\hline Cropping system & Time of application & $\begin{array}{c}\text { Fertilizer } \\
\mathrm{N}^{\mathrm{P}} \mathrm{P}_{2} \mathrm{O}_{5}: \mathrm{K}_{2} \mathrm{O} \\
12: 24: 12\end{array}$ & $\mathrm{~N}$ \\
\hline & & \multicolumn{2}{|l|}{$\mathrm{kg} / \mathrm{ha}$} \\
\hline Yam as a monocrop & 6 weeks from planting & 730 & 0 \\
\hline \multicolumn{4}{|l|}{$\begin{array}{l}\text { Yam intercropped with Irish po- } \\
\text { tato followed by radish and } \\
\text { peanut: }\end{array}$} \\
\hline \multirow[t]{3}{*}{ (1) Yam intercrop } & 6 weeks after planting & 300 & 0 \\
\hline & 14 weeks after planting & 300 & 0 \\
\hline & 28 weeks after planting & 130 & 20 \\
\hline \multirow[t]{2}{*}{ (2) Irish potato intercrop } & At time of sowing & 365 & 0 \\
\hline & At flowering & 0 & 20 \\
\hline (3) Radish intercrop & No fertilizer applied & 0 & 0 \\
\hline \multirow[t]{2}{*}{ (4) Peanut intercrop } & At time of sowing & 365 & 0 \\
\hline & At flowering & 0 & 20 \\
\hline
\end{tabular}

in the furrow at $5-7.5 \mathrm{~cm}$ below the seeding depth. At the flowering stages of the intercrops, urea was placed in circular bands $5-7.5 \mathrm{~cm}$ away from the furrow at a depth of $5-7.5 \mathrm{~cm}$.

Weeding was done manually. Control of diseases and pests was achieved by spraying as often as necessary. Daconil $(90 \mathrm{~g})$ and Kocide ${ }^{5}$ $(90 \mathrm{~g})$ were applied three times, particularly for the Irish potato intercrop. Table 3 shows the planting and harvesting dates for first and second years.

\footnotetext{
${ }^{5}$ Trade names in this publication are used only to provide specific information. Mention of a trade name does not constitute a warranty of equipment or materials by the Agricultural Experiment Station of the University of Puerto Rico, nor is this mention a statement of preference over other equipment or materials.
} 
TABLE 2.-Planting and harvesting dates, Olive River 1980-1982

\begin{tabular}{|c|c|c|c|c|c|c|}
\hline \multirow{2}{*}{ Crop } & \multicolumn{3}{|c|}{ First year experiment } & \multicolumn{3}{|c|}{ Second year experiment } \\
\hline & Planted & Harvested & Crop cycle & Planted & Harvested & Crop crycle \\
\hline & & & Length & & & \\
\hline Yam & March 26, 1980 & January 29, 1981 & 300 days & February 20, 1981 & January 11, 1982 & 320 days \\
\hline \multicolumn{7}{|l|}{ Intercrops: } \\
\hline Irish potato & March 27, 1980 & July 3, 1980 & 97 days & March 28, 1981 & July 7, 1981 & 100 days \\
\hline Radish & July 29, 1980 & Sept. 10, 1980 & 44 days & None & None & Not planted \\
\hline Peanut & Sept. 18, 1980 & - & None & None & None & Not planted \\
\hline
\end{tabular}


To eliminate the possible effect of "seed" size on yam yield, heads were selected for uniformity of weight. At planting, each head was weighed and recorded so that following harvest of the yam any relationships between size of planting material and yield could be determined. Each plot had 32 yam heads with an average weight of $0.87 \mathrm{~kg}$, i.e., $6.96 \mathrm{t} / \mathrm{ha}$ (8,000 heads/ha) were planted.

In the case of the Irish potato, propagation material of the Red Pontiac variety was used. In each plot, 133 seedpieces were planted for a population of $33,250 /$ ha. Weight of seed material was kept constant at 10.4 $\mathrm{kg} / \mathrm{plot}$ for a total of $2.6 \mathrm{t} / \mathrm{ha}$.

Radish was seeded directly to produce $125,000 /$ ha and peanuts were sown at the rate of $75 \mathrm{~kg} / \mathrm{ha}$ or $300 \mathrm{~g} /$ plot for a population of $63,000 / \mathrm{ha}$.

TABLE 3.-Total yields of yellow yams (Dioscorea cayenensis) in monocrop and in multiple cropping systems grown on runoff plots at Olive River, 1980-1982

\begin{tabular}{|c|c|c|c|c|c|c|}
\hline \multirow{2}{*}{ Treatment $^{1}$} & \multirow{2}{*}{ Cropping system } & \multicolumn{2}{|c|}{$\begin{array}{c}\text { Total yellow yam } \\
\text { tuber yield }\end{array}$} & \multicolumn{2}{|c|}{$\begin{array}{l}\text { Total Irish } \\
\text { potato yield }\end{array}$} & \multirow{2}{*}{ Radish yield? } \\
\hline & & $\begin{array}{c}1 \text { st } \\
\text { year }\end{array}$ & $\begin{array}{l}2 \mathrm{nd} \\
\text { year }\end{array}$ & $\begin{array}{l}1 \text { st } \\
\text { year }\end{array}$ & $\begin{array}{l}2 \text { nd } \\
\text { year }\end{array}$ & \\
\hline & & \multicolumn{5}{|c|}{ t/ha } \\
\hline 1 & Yam monocrop & $\begin{array}{l}64.1 \\
(0)^{3}\end{array}$ & $\begin{array}{l}62.0 \\
(0)\end{array}$ & - & - & \\
\hline 2 & $\begin{array}{l}\text { Yam + Irish potato } \\
\text { + radish }\end{array}$ & $\begin{array}{c}53.9 \\
(-15.9)\end{array}$ & $\begin{array}{c}50.9 \\
(-17.9)\end{array}$ & 11.9 & 9.7 & 1.6 \\
\hline 3 & $\begin{array}{l}\text { Yam + Irish potato } \\
\text { + radish }\end{array}$ & $\begin{array}{c}42.2 \\
(-34.2)\end{array}$ & $\begin{array}{c}45.0 \\
(-27.4)\end{array}$ & 13.8 & 14.4 & 1.3 \\
\hline 4 & $\begin{array}{l}\text { Yam + Irish potato } \\
\text { + radish }\end{array}$ & $\begin{array}{c}42.2 \\
(-34.2)\end{array}$ & $\begin{array}{c}45.5 \\
(-26.6)\end{array}$ & 13.7 & 11.9 & 1.3 \\
\hline
\end{tabular}

${ }^{1}$ Treatments have the confounding effect of different soil conservation measures.

${ }^{2}$ Radish yield for the first year only.

${ }^{3}$ Change in total yam yield over monocrop, \%.

\section{MEASUREMENT OF CROP PRODUCTION}

At harvest, fresh yam edible root weight was recorded after the portion of the proximal end to be used for planting material was severed and weighed. The remainder was classified into marketable and unmarketable portions on the basis of firmness, appearance, shape and disease free condition.

Irish potatoes were classified into marketable and nonmarketable tubers on the basis of size, firmness and disease and insect-free condition. Tubers which were mature, but small, were considered as seed material, whereas undeveloped immature tubers were classified as unmarketable. Radishes were considered marketable if they were round to oval and not larger than a ping-pong ball. The peanut intercrop was abandoned after 
it became clear that because of excessive shading from the yam canopy, normal crop growth and development were impaired. For the second experimental year, only the Irish potato was used as an intercrop with yam.

\section{RESULTS AND DISCUSSION}

Table 3 presents data on total yields for each crop year. Statistical analysis for components of yam yields (total, "new heads", marketable, unmarketable) did not reveal significant differences in any of the variables in either the first or the second year experiments. This was probably because of the limitations of the experimental design used, since yield ranged from a low of $42.2 \mathrm{t} / \mathrm{ha}$ to a high of $64.1 \mathrm{t} / \mathrm{ha}$ in the first year and from $45.5 \mathrm{t} / \mathrm{ha}$ to $62.0 \mathrm{t} / \mathrm{ha}$ in the second year.

Yam yields were very good when compared with those obtained by farmers in the project area (10-15 t/ha of marketable edible roots). The 2-year average of marketable tubers was 33.9, 29.9, 20.4 and $21.4 \mathrm{t} / \mathrm{ha}$ for treatments 1, 2, 3, and 4, respectively. Gross yam edible root yields were always higher in the check plot (T-1) followed by Treatment 3. Treatments 3 and 4 were the lowest yielders in both years (table 3).

A combined analysis for the 2-year data was made, and with the increase in degrees of freedom in the error term and other variables, a significant difference could then be detected. This indicates a real difference in yam yields between treatments. It is apparent that, under Olive River conditions, the intercrops have an adverse effect on yam yields. This is attributable to competition for available nutrients, moisture and space. Differences in yield could also be due to uneven number of yam stakes between treatments: 20 stakes for Treatment 1 (5,000/ha), 16 for Treatment $2(4,000 / \mathrm{ha})$ and 10 for Treatments 3 and 4 (2,500/ha). For Treatments 1 and 2 (both on individual hills) each hill was provided with one bamboo stake (5-6 $\mathrm{m}$ long) to accommodate the twining yam vine. However, in Treatments 3 and 4 (both on continuous mounds) stakes were placed between pairs of mounds and each carried four yam vines (two from each mound). The effect on yields in this particular case was one of photosynthesis opportunity.

The adverse effect of the intercrops on yam yield was offset in part by the extra income obtained from the different associated crops. Gross Irish potato yields ranged from 12 to $14 \mathrm{t} / \mathrm{ha}$ and total yields of radish ranged from 1.3 to $1.6 \mathrm{t} / \mathrm{ha}$. In addition to the extra cash flow benefits provided by the intercrops, subsistence farmers could enhance their nutritional profile while at the same time minimize farming risks and reduce soil erosion.

One of the four soil conservation alternatives tested at Olive River was a Napier grass buffer strip (T-4), which is one of the most promising 
species of grass for the hillsides of Jamaica since it can be established with relative ease and serves as a good source of fodder for cattle.

During the 2 experimental years, the buffer strips of Napier grass were harvested 8 times totalling an average of $274 \mathrm{~kg} / \mathrm{plot}$ or 68.5 ton/ha. Under the conditions at Olive River it is possible to harvest the Napier grass 4 to 5 times yearly and obtain an average of about 42 to 48 ton/ha from the small piece of land used for the buffer strip.

Grass barrier strips were the most effective (jointly with T-3) in reducing soil losses and also the less costly of all soil conservation treatments tested in Olive River. ${ }^{3}$

Contour buffer strips of Napier grass should be promoted especially among livestock farmers in the Olive River Watershed and similar ecological areas. Buffer strips other than grasses should be tested since they could provide, besides the soil conservation effects, extra cash income to farmers and/or utilize local material that otherwise would be wasted.

\section{RESUMEN}

Se compararon varios sistemas de producción de ñame en las parcelas previamente utilizadas para medir las pérdidas de suelo en la cuenca del Rio Olive. Los rendimientos de ñame amarillo fluctuaron de un año a otro de entre 42 a $63 \mathrm{Tm} / \mathrm{ha}$. Sin embargo, estas diferencias no fueron significativas en ninguno de los dos años considerados individualmente. Los rendimientos de ñame comercial constituyeron $47 \%$ y $57 \%$ de la producción total en los primer y segundo años, respectivamente. Cuando se intercaló la siembra de ñames con la de papas, los rendimientos de esta última fluctuaron entre 12 y $14 \mathrm{Tm} / \mathrm{ha}$. Los rendimientos de papa comercial fueron de 80 a $85 \%$ de la producción total. Los bajos rendimientos de ñame en los casos en que se intercalaron otras cosechas se compensaron por la producción adicional de estas otras cosechas. Cuando se hizo un análisis estadístico combinado de los datos de los dos años experimentales, las diferencias entre tratamientos fueron significativas. Las cosechas intercaladas redujeron significativamente los rendimientos de ñame. La franja amortiguadora de yerba Napier produjo de 42 a 48 $\mathrm{Tm} / \mathrm{ha}$ de forraje verde. Las alternativas a la construcción de bancales, tales como zanjas de ladera y franjas amortiguadoras de yerba, en relación con aumentos en la producción de ñame y con la diversificación agrícola de las zonas montañosas, son menos costosas, más sencillas, fáciles de hacer y muy eficaces en términos de conservación de suelos. 